\title{
SIFAT FISIKA TANAH PERKEBUNAN KELAPA SAWIT (Elaeis guineensis Jacq.) SETELAH DIAPLIKASI TANDAN KOSONG KELAPA SAWIT DAN LIMBAH CAIR PABRIK KELAPA SAWIT
}

\section{The Physical Nature of the Land of Oil Palm (Elaeis guineensis Jacq) Platations after Being Applied to Oil Palm Empty Bunches and Palm Oil Mill Effluent}

\author{
Maysarah dan Nelvia \\ JurusanAgroteknologi, FakultasPertanian,Universitas Riau \\ Email: Maysarah310@gmail.com/+6282174566612 \\ [Diterima Januari 2018; Disetujui April 2018]
}

\begin{abstract}
The research aims to examine the effect of the application of waste processing palm oil mill (Empty Fruit Bunches and Palm Oil Mill Effluent) on soil physical properties. The research was conducted at the oil palm plantation at Pelalawan and Laboratory of Soil Science, Faculty of Agriculture, the University of Riau from March to May 2016. The study was conducted experimentally using a Completely Randomized Design (CRD), which consisted of 4 treatments (EFB, POME, EFB+POME and without application as control). Each treatment was repeated 3 times. EFB and POME have been applied to the land since 2001 with intervals giving every 6 months. Soil samples were applied EFB, POME, and EFB+POME taken on Blocks B3, Blocks B7 and Blocks C17. Soil samples were taken at a depth of $0-15 \mathrm{~cm}$ and $15-30 \mathrm{~cm}$ for disturbed and undisturbed soil. Parameters measured were soil water content, bulk density, particle density, total pore space, permeability, and soil color. Each parameter of the observed data was statistically analyzed using analysis of variance followed by Duncan's New Multiple Range Test (DNMRT) at 5\% level, while the soil color was descriptively analyzed. The results showed that the application of a mixture of EFB+POME increased soil moisture and bulk density decrease significantly and tended to increase the total pore space and permeability and tends to be lower particle density than controls, but it was not evident when compared EFB applications and POME alone. Applications waste processing palm oil mill affected the color of the soil where the soil is black on the application mix EFB+POME (hue: 10 YR, value/chroma: 2/1), brown on the application EFB (hue: $10 \mathrm{YR}$, value/chroma: 4/3 ), dark brown on the application of POME (hue: $10 \mathrm{YR}$, value/chroma: 3/3) and yellowish-brown in without application (hue: $10 \mathrm{YR}$, value/chroma: 5/4).
\end{abstract}

Keywords: Empty fruit bunches, Palm oil mill effluent, Soil physical properties

\begin{abstract}
ABSTRAK
Penelitian bertujuan untuk mempelajari pengaruh aplikasi limbah pabrik pengolahan kelapa sawit (tandan kosong kelapa sawit dan limbah cair) terhadap sifat fisika tanah. Penelitian dilaksanakan di lahan perkebunan kelapa sawit di Kabupaten Pelalawan dan Laboratorium Ilmu Tanah, Fakultas Pertanian, Universitas Riau dari Maret sampai Mei 2016. Penelitian dilakukan secara eksperimen menggunakan Rancangan Acak Lengkap (RAL) terdiri dari 4 perlakuan (TKKS, LC, campuran TKKS + LC dan tanpa aplikasi sebagai kontrol), setiap perlakuan diulang 3 kali. Aplikasi TKKS dan LC sejak tahun 2001 dengan interval setiap 6 bulan sekali. Aplikasi TKKS, LC dan campuran TKKS + LC masing-masing pada Blok B3, Blok B7 dan Blok C17. Parameter yang diamati adalah kadar air tanah, bulk density, particle density, total ruang pori, permeabilitas dan warna tanah. Data hasil pengamatan tiap parameter dianalisis secara statistik menggunakan sidik ragam dan dilanjutkan dengan Duncan's New Multiple Range Test (DNMRT) pada taraf 5\% sedangkan warna tanah dianalisis secara deskriptif. Hasil penelitian menunjukkan bahwa aplikasi campuran TKKS + LC meningkatkan kadar air tanah dan menurunkan bulk density secara nyata serta cenderung meningkatkan total ruang pori dan permeabilitas dan cenderung menurunkan particle
\end{abstract}


density dibandingkan kontrol, tetapi tidak nyata bila dibandingkan aplikasi TKKS dan LC secara tunggal. Aplikasi limbah PPKS berpengaruh terhadap warna tanah dimana tanah berwarna hitam pada aplikasi campuran TKKS + LC (hue: 10 YR, value/chroma : 2/1), berwarna cokelat pada aplikasi TKKS (hue: 10 YR, value/chroma : 4/3), berwarna cokelat tua pada aplikasi LC (hue: 10 YR, value/chroma : 3/3) dan berwarna cokelat kekuningan pada tanpa aplikasi (hue: $10 \mathrm{YR}$, value/chroma : 5/4).

\section{Kata kunci : Tandan kosong kelapa sawit, Limbah cair, Sifat fisika tanah}

\section{PENDAHULUAN}

Tanaman kelapa sawit (Elaeis guineensis Jacq.) merupakan komoditas perkebunanyang hingga saat ini masih menjadi unggulan di Indonesia, karena mempunyai kontribusi yang besar dalam penyediaan lapangan kerja, pertumbuhan ekonomi dan sumber devisa negara bila dibandingkan dengan sektor pertanian lainnya. Hal tersebut dikarenakan permintaan pasar terhadap produk kelapa sawit baik crude palm oil (CPO) maupun produk olahan lainnya sangat besar, sehingga perkebunan kelapa sawit sangat potensial untuk dikembangkan. Data Statistik Dinas Perkebunan Provinsi Riau (2015) mencatat luas areal perkebunan kelapa sawit Provinsi Riau pada tahun 2015 telah mencapai 2.398.328 ha dengan total produksi tandan buah segar (TBS) sebesar 7.442.557 ton. Jumlah luas areal lahan kelapa sawit pada tahun 2015 lebih besar dibandingkan tahun 2014 yang hanya sebesar 2.296.849 ha dengan total produksi TBS sebesar 7.037.636 ton. Perluasan lahan kelapa sawit tersebut tidak saja pada lahan pertanian yang produktif tetapi juga pada lahan marjinal. Salah satu lahan marjinal yang berpotensi dalam pengembangan kelapa sawit di Indonesia yaitu tanah Ultisol.

Tanah Ultisol termasuk bagian terluas dari lahan kering yang ada di Indonesia yaitu 45.794.000 ha atau sekitar $25 \%$ dari total luas daratan Indonesia (Subagyo, et al., 2000). Ditinjau dari luasnya, tanah Ultisol mempunyai potensi untuk pengembangan pertanian lahan kering. Namun demikian, pemanfaatan tanah ini menghadapi kendala karakteristik tanah yang dapat menghambat pertumbuhan tanaman apabila tidak dikelola dengan baik. Beberapa kendala yang umum pada tanah Ultisol yaitu masalah pemadatan tanah, distribusi pori yang kurang seimbang karena didominasi oleh pori mikro sehingga menyebabkan aerasi kurang baik, laju infiltrasi rendah dan peka terhadap erosi. Selanjutnya, kemantapan agregat dan permeabilitas tanah juga rendah karena kandungan bahan organik yang rendah.

Solusi yang dapat dilakukan untuk memperbaiki permasalahan tanah Ultisol tersebut yaitu dengan pemberian bahan organik, selain dapat meningkatkan biologi dan kimia tanah juga mempunyai peranan penting dalam memperbaiki sifat fisik tanah. Bahan organik yang digunakan adalah tandan kosong kelapa sawit dan limbah cair pabrik kelapa sawit.

Tanah yang diberi perlakuan tandan kosong kelapa sawit $(5,10$ dan 20 ton/ha) memiliki kadar air tanah yang lebih tinggi dibandingkan tanpa pemberian tandan kosong kelapa sawit (Ichriani, et al., 2012). Pemberian limbah cair akan dapat meningkatkan aktifitas mikroba tanah. Mikrobaberperan sebagai perombak sekunder dalam mengurai bahan organik dan membentuk struktur yang remah dan membuat pori-pori di dalam tanah lebih banyak dan gembur sehingga bobot isi menjadi rendah. Hasil penelitian Ketaren (2010) menunjukkan bahwa pemberian limbah cair pabrik kelapa sawit berpengaruh nyata dalam meningkatkan C-Organik tanah tapi tidak berpengaruh nyata dalam memperbaiki sifat fisik tanah, meskipun demikian pemberian limbah cair dapat menurunkan bobot isi, meningkatkan total ruang pori tanah, dan meningkatkan laju permeabilitas tanah. Berdasarkan hal tersebut penelitian ini dilakukan untuk mempelajari pengaruh aplikasi limbah pabrik pengolahan kelapa sawit (PPKS) yaitu tandan kosong kelapa sawit (TKKS) dan limbah cair (LC) terhadap sifat fisika tanah.

\section{METODE PENELITIAN}

Penelitian lapangan dilaksanakan di PT. Sari Lembah Subur, Kabupaten Pelalawan dan analisis sifat fisika tanah dilakukan di Laboratorium Ilmu Tanah Fakultas Pertanian Universitas Riau Kampus Bina Widya. 
Penelitian dilaksanakan dari bulan Maret sampai Mei 2016.

Bahan yang digunakan dalam penelitian adalah sampel tanah, kertas label, plastik bening, karet gelang dan tali rafia dan alat yang digunakan antara lain penggaris/meteran, bor belgi, ring sampel, munsell soil color chart, cangkul, pisau cutter, alat tulis, spidol, gunting dan kamera. Alat yang digunakan di laboratorium yaitu oven, timbangan analitik, gelas ukur, kompor, cawan dan peralatan untuk analisis sifat fisik lainnya.

Penelitian dilaksanakan secara eksperimen menggunakan Rancangan Acak Lengkap (RAL) yang terdiri dari 4 perlakuan, yaitu: A: aplikasi TKKS, B: aplikasiLC, C:aplikasi TKKS + LC, D: tanpa aplikasi (kontrol) setiap perlakuan diulang 3 kali. Kedua jenis limbah tersebut telah diaplikasikan ke lahan sejak tahun 2001 (selama 15 tahun) dengan interval pemberian setiap 6 bulan. Sampel tanah yang diaplikasi TKKS, LC dan campuran TKKS + LC diambil pada Blok B3 (7,59 ha), Blok B7 (33 ha) dan Blok C17 (19,81 ha) dan tanpa aplikasi di Blok lainnya. Pada setiap blok sampel tanah diambil pada kedalaman 0-15 cm dan 15-30 cm dengan ring sampel (tanah tidak terganggu) dan terganggu pada 2 titik. Titik pengambilan sampel masingmasing untuk aplikasi TKKS yaitu pada jarak $30 \mathrm{~cm}$ dari pinggir piringan dan ditengah gawangan sedangkan aplikasi LC dan campuran TKKS + LC diambil pada $30 \mathrm{~cm}$ dari Flatbed dan di pinggir piringan.

Parameter yang diamati adalah kadar air tanah, bulk density, particle density, total ruang pori, permeabilitas dan warna tanah. Data hasil pengamatan tiap parameter dianalisis secara statistik menggunakan sidik ragam dan dilanjutkan dengan Duncan's New Multiple Range Test (DNMRT) pada taraf 5\% sedangkan warna tanah dianalisis secara deskriptif.

\section{HASIL DAN PEMBAHASAN}

\section{Kadar AirTanah}

Tabel 1 menunjukkan bahwa aplikasi LC dan campuran TKKS + LC meningkatkan kadar air tanah pada kedalaman 0-15 cm dan 15-30 $\mathrm{cm}$ secara nyata dibandingkan kontrol dan TKKS kecuali pada kedalaman 0-15 cm untuk aplikasi TKKS tidak nyata.

Tabel 1. Kadar air tanah di bawah tegakan kelapa sawit setelah aplikasi limbah pabrik pengolahan kelapa sawit (\%)

\begin{tabular}{lcc}
\hline \multirow{2}{*}{ Limbah Pabrik Pengolahan Kelapa Sawit } & \multicolumn{2}{c}{ Kedalaman Tanah $(\mathrm{cm})$} \\
\cline { 2 - 3 } & $0-15$ & $15-30$ \\
\hline Kontrol & $23,71 \mathrm{~b}$ & $23,00 \mathrm{~b}$ \\
TKKS & $33,76 \mathrm{ab}$ & $24,45 \mathrm{~b}$ \\
LC & $43,38 \mathrm{a}$ & $42,10 \mathrm{a}$ \\
TKKS + LC & $51,86 \mathrm{a}$ & $49,31 \mathrm{a}$ \\
\hline
\end{tabular}

Keterangan: Angka-angka yang diikuti oleh huruf kecil yang sama menunjukkan berbeda tidak nyata menurut uji lanjut DNMRT pada taraf $5 \%$

Hal ini disebabkan oleh aplikasi campuran TKKS + LC menyumbangkan bahan organik ke tanah lebih banyak dibandingkan aplikasi TKKS dan LC secara tunggal. TKKS akan terdekomposisi lebih cepat karena LC mengandung mikroorganisme sebagai dekomposer. Darnoko, et al. (1993) menyatakan bahwa LC mengandung mikroorganisme yang dapat menguraikan bahan organik seperti Rhizobium, Acetobacter dan Nitrosomonas yang dapat mendegradasi senyawa nitrogen organik serta mikroorganisme pengurai senyawa karbon dan fosfor organik seperti Aspergillus ustus dan Pseudomonas. Bahan organik yang telah terdekomposisi akan menyumbangkan humus ke dalam tanah yang dapat menahan air. Sejalan dengan pendapat Lumbanraja (2012) yang menyatakan bahwa bahan organik dalam bentuk humus berperan meningkatkan kapasitas menahan air tanah.Hal ini juga sejalan dengan pernyataan Stevenson (1997) yang menyatakan bahwa bahan organik yang telah mengalami pelapukan mempunyai kemampuan yang cukup tinggi dalam memegang air karena bersifat hidrofilik, sehingga dengan demikian dapat membuat air selalu tersedia. Arsyad (2000) juga menyatakan 
bahwa bahan organik memiliki kemampuan menyerap air yang tinggi, serapan air oleh bahan organik mencapai dua sampai tiga kali bobot bahan organik tersebut.

\section{Bobot Isi Tanah (Bulk density)}

Tabel 2 menunjukkan bahwa aplikasi campuran TKKS + LC menurunkan bulk density pada kedalaman 0-15 cm dan $15-30 \mathrm{~cm}$ secaranyatadibandingkankontrol dan TKKS kecuali pada kedalaman $15-30 \mathrm{~cm}$ untuk aplikasi TKKS tidak nyata dan juga berbeda tidak nyata dibandingkan aplikasi LC pada kedua kedalaman tersebut.

Tabel 2. Bulk density tanah di bawah tegakan kelapa sawit setelah aplikasi limbah pabrik pengolahan kelapa sawit $\left(\mathrm{g} / \mathrm{cm}^{3}\right)$

\begin{tabular}{lcc}
\hline \multirow{2}{*}{ Limbah Pabrik Pengolahan Kelapa Sawit } & \multicolumn{2}{c}{ Kedalaman Tanah $(\mathbf{c m})$} \\
\cline { 2 - 3 } & $\mathbf{0}-\mathbf{1 5}$ & $\mathbf{1 5}-\mathbf{3 0}$ \\
\hline Kontrol & $1,29 \mathrm{a}$ & $1,35 \mathrm{a}$ \\
TKKS & $1,27 \mathrm{a}$ & $1,31 \mathrm{ab}$ \\
LC & $1,13 \mathrm{ab}$ & $1,23 \mathrm{ab}$ \\
TKKS + LC & $0,97 \mathrm{~b}$ & $1,14 \mathrm{~b}$ \\
\hline
\end{tabular}

Keterangan: Angka-angka yang diikuti oleh huruf kecil yang sama menunjukkan berbeda tidak nyata menurut uji lanjut DNMRT pada taraf 5\%

Kriteria bulk density di kedalaman tanah 0-15 cm termasuk kriteria rendah sampai sedang, sedangkan di kedalaman $15-30 \mathrm{~cm}$ termasuk kriteria sedang. Hal ini disebabkan semakin banyak limbah PPKS yang diaplikasikan maka semakin banyak bahan organik yang disumbangkan ke dalam tanah. Bahan organik dalam tanah berperan sebagai perekat (pengikat) partikel tanah sehingga agregasi tanah menjadi baik, ruang pori tanah meningkat dan berat isi menurun. Hal ini sesuai dengan pernyatan Thamrin (2000), dalam Mariana (2006) bahwa bahan organik bersifat porous, ketika diberikan ke dalam tanah maka berat isi tanah menjadi rendah.

Limbah PPKS yang diberikan dapat menciptakan lingkungan yang baik bagi aktivitas biota tanah dalam mendekomposisi bahan organik. Hal ini berlangsung dengan mekanisme penambahan bahan organik dapat meningkatkan populasi mikroorganisme tanah, diantaranya yaitu cendawan dan bakteri, dimana bahan organik digunakan oleh mikroorganisme tanah sebagai penyusun tubuh dan sumber energinya. Hifa ataupun miselia cendawan mampu menyatukan butir tanah menjadi agregat sedangkan bakteri berfungsi sebagai perekat yang menyatukan agregat tersebut. Kemantapan agregat yang semakin tinggi dapat menurunkan bulk density tanah dengan demikian maka persentase ruang pori semakin besar dan kapasitas mengikat air semakin tinggi (Kartasapoetra, 2005).

\section{Kerapatan Partikel Tanah (Particle density)}

Tabel 3 menunjukkan bahwa aplikasi TKKS, LC dancampuran TKKS + LC menurunkan particle density pada kedalaman 0-15 cm dan $15-30 \mathrm{~cm}$ secara tidak nyata dibandingkan kontrol.

Tabel 3. Particle density di bawah tegakan kelapa sawit setelah aplikasi limbah pabrik pengolahan kelapa sawit $\left(\mathrm{g} / \mathrm{cm}^{3}\right)$

\begin{tabular}{lcc}
\hline \multirow{2}{*}{ Limbah Pabrik Pengolahan Kelapa Sawit } & \multicolumn{2}{c}{ Kedalaman Tanah (cm) } \\
\cline { 2 - 3 } & $\mathbf{0}-\mathbf{1 5}$ & $\mathbf{1 5}-\mathbf{3 0}$ \\
\hline Kontrol & $2,60 \mathrm{a}$ & $2,69 \mathrm{a}$ \\
TKKS & $2,51 \mathrm{a}$ & $2,68 \mathrm{a}$ \\
LC & $2,41 \mathrm{a}$ & $2,55 \mathrm{a}$ \\
TKKS + LC & $2,39 \mathrm{a}$ & $2,43 \mathrm{a}$ \\
\hline
\end{tabular}

Keterangan: Angka-angka yang diikuti oleh huruf kecil yang sama menunjukkan berbeda tidak nyata menurut uji lanjut DNMRT pada taraf $5 \%$ 
Hal ini diduga pemberian limbah PPKS belum mampu menggemburkan tanah atau belum mampu membuat kondisi tanah lebih sarang. Sarief (1989) menyatakan particle density tanah dipengaruhi oleh pengolahan tanah, bahan organik, pemadatan oleh alat-alat pertanian, tekstur, struktur dan kandungan air tanah. Menurut Wijaya (2009) dalam Irvan (2010) salah satu faktor yang mempengaruhi particle density tanah adalah tekstur tanah. Tekstur tanah merupakan salah satu karakteristik tanah yang tidak mudahberubah oleh perlakuan agronomis, sehingga pemberian limbah PPKS tidak mampu merubah particle density tanah secara signifikan. Lapisan bawah tanah merupakan horizon argilik dimana horizon argilik ini mempunyai kandungan liat yang lebih tinggi daripada horizon di atasnya sehingga struktur tanahnya kurang mantap (Soil Survey Staff, 1990). Struktur tanah yang kurang mantap dan rendahnya kandungan bahan organik dalam tanah dapat mempengaruhi nilai bulk density, particle density tanah dan porositas tanah. Struktur yang kurang mantap dapat mengakibatkan tanah menjadi mudah terdispersi yang dapat menyumbat pori-pori tanah dan menyebabkan tanah menjadi lebih padat dan menambah massa tanah sehingga bulk density dan particle density menjadi semakin tinggi dan ruang pori berkurang.

\section{Total Ruang Pori Tanah}

Tabel 4 menunjukkan bahwa aplikasi TKKS, LC dan campuran TKKS + LC meningkatkan total ruang poripada kedalaman 0-15 cm dan $15-30 \mathrm{~cm}$ secara tidak nyata dibandingkan kontrol.

Tabel 4. Total ruang pori tanah di bawah tegakan kelapa sawit setelah aplikasi limbah pabrik pengolahan kelapa sawit (\%)

\begin{tabular}{lcc}
\hline \multirow{2}{*}{ Limbah Pabrik Pengolahan Kelapa Sawit } & \multicolumn{2}{c}{ Kedalaman Tanah (cm) } \\
\cline { 2 - 3 } Kontrol & $\mathbf{0 - 1 5}$ & $\mathbf{1 5}-\mathbf{3 0}$ \\
TKKS & $50,38 \mathrm{a}$ & $49,81 \mathrm{a}$ \\
LC & $51,29 \mathrm{a}$ & $51,11 \mathrm{a}$ \\
TKKS + LC & $53,11 \mathrm{a}$ & $51,76 \mathrm{a}$ \\
\hline K & $59,41 \mathrm{a}$ & $53,08 \mathrm{a}$ \\
\hline
\end{tabular}

Keterangan: Angka-angka yang diikuti oleh huruf kecil yang sama menunjukkan berbeda tidak nyata menurut uji lanjut DNMRT pada taraf $5 \%$

Terdapat kecenderungan bahwa limbah PPKS yang diaplikasikan secara bersamaan (campuran) menunjukkan peningkatan total ruang pori yang cenderung semakin besar. Hal ini disebabkan oleh semakin banyak limbah PPKS yang diaplikasikan maka semakin banyak bahan organik yang disumbangkan ke dalam tanah. Hal ini sesuai dengan pendapat Hardjowigeno (2003), bahwa porositas dipengaruhi oleh bahan organik. Makin tinggi bahan organik maka semakin rendah bobot volume tanah dan semakin tinggi total ruang pori tanah. Yulnafatmawita, et al. (2008) juga menyatakan bahwa pemberian bahan organik tanah menurunkan nilai bobot isi tanah dan meningkatkan persentase total ruang pori tanah.

Dilihat dari Tabel 4 kriteria total ruang pori setelah aplikasi limbah PPKS pada kedalaman 0-15 cm maupun 15-30 cm termasuk kedalam kelas baik. Hal ini disebabkan oleh bahan organik pada tanah akan menyebabkan kondisi tanah menjadi sarang karena bahan organik akan menempati ruang diantara partikel tanah sehingga tanah menjadi porous. Hasil penelitian Muyassir, et al. (2012) mendapatkan bahwa total porositas tanah cenderung meningkat seiring dengan meningkatnya dosis bahan organik yang diberikan baik secara tunggal maupun yang telah mendapat pencampuran dengan bahan organik lainnya dengan hasil rata-rata total porositas tanah akibat interaksi perlakuan yang dicobakan berkisar antara 52\%-59,67\%.

\section{Permeabilitas Tanah}

Tabel 5 menunjukkan bahwa aplikasi TKKS, LC dan campuran TKKS + LC meningkatkan permeabilitas pada kedalaman 0$15 \mathrm{~cm}$ dan $15-30 \mathrm{~cm}$ secara tidak nyata dibandingkan kontrol. Tinggi rendahnya nilai permeabilitas dipengaruhi oleh total ruang pori tanah, sehingga tanah dengan total ruang pori 
yang tinggi akan mengurangi pemadatan tanah. Hal ini sesuai dengan pendapat Mauli (2008) yang menyatakan bahwa permeabilitas erat kaitannya dengan total ruang pori tanah, dimana semakin besar total ruang pori tanah maka semakin besar pula permeabilitas tanah. Artinya laju pergerakan air semakin besar apabila total ruang pori di dalam tanah besar. Total ruang pori tanah yang tinggi dan berat volume yang rendah akan menyebabkan air mudah masuk ke dalam tanah, ditahan dan diteruskan lebih dalam dan akhirnya meningkatkan permeabilitas tanah. Sarief (1989) mengatakan nilai permeabilitas tanah adalah laju pergerakan air dalam tanah melalui media berpori (tanah) yang berpengaruh terhadap kadar air dan pertumbuhan tanaman. Arsyad (2000) menyatakan bahwa tanah dengan struktur yang baik dan mantap lebih tahan terhadap erosi dibandingkan tanah dengan struktur yang kurang mantap, karena struktur yang mantap lebih tahan dan lebih banyak meloloskan air sehingga permeabilitas semakin tinggi.

Tabel 5. Permeabilitas tanah di bawah tegakan kelapa sawit setelah aplikasi limbah pabrik pengolahan kelapa sawit $(\mathrm{cm} / \mathrm{jam})$

\begin{tabular}{lcc}
\hline \multirow{2}{*}{ Limbah Pabrik Pengolahan Kelapa Sawit } & \multicolumn{2}{c}{ Kedalaman Tanah (cm) } \\
\cline { 2 - 3 } Kontrol & $\mathbf{0}-\mathbf{1 5}$ & $\mathbf{1 5}-\mathbf{3 0}$ \\
TKKS & $20,79 \mathrm{a}$ & $17,68 \mathrm{a}$ \\
LC & $22,39 \mathrm{a}$ & $17,78 \mathrm{a}$ \\
TKKS + LC & $24,48 \mathrm{a}$ & $20,17 \mathrm{a}$ \\
Keterangan: Angka-angka yang diikuti oleh huruf kecil yang sama menunjukkan berbeda tidak nyata menurut uji lanjut & $32,03 \mathrm{a}$ \\
&
\end{tabular}

\section{Warna Tanah}

Hasil pengamatan warna tanah di bawah tegakan tanaman kelapa sawit yang telah diaplikasikan beberapa jenis limbah pabrik pengolahan kelapa sawit disajikan pada tabel 6 . Warna tanah yang paling gelap terdapat pada lapisan atas (kedalaman 0-15 cm) adalah
aplikasiTKKS + LC yang ditetapkan dengan Munsell Soil Color Chart adalah 10 YR 2/1 yaitu black atau hitam. Lapisan ini berwarna gelap karena mengandung bahan organik. Bahan organik ini berasal dari 2 limbah PPKS (TKKS dan LC) yang mengalami peruraian yang akan mempunyai warna cenderung lebih hitam.

Tabel 6. Warna tanah di bawah tegakan kelapa sawit setelah aplikasi beberapa jenis limbah pabrik pengolahan kelapa sawit

\begin{tabular}{|c|c|c|c|}
\hline \multirow{2}{*}{$\begin{array}{c}\text { Limbah Pabrik Pengolahan } \\
\text { Kelapa Sawit }\end{array}$} & \multicolumn{3}{|c|}{ Kedalaman Tanah 0-15 cm } \\
\hline & Hue & Value/Chroma & Warna \\
\hline Kontrol & $10 \mathrm{YR}$ & $5 / 4$ & Coklat Kekuningan \\
\hline TKKS & $10 \mathrm{YR}$ & $4 / 3$ & Coklat \\
\hline $\mathrm{LC}$ & $10 \mathrm{YR}$ & $3 / 3$ & Coklat Tua \\
\hline TKKS + LC & $10 \mathrm{YR}$ & $2 / 1$ & Hitam \\
\hline \multicolumn{4}{|c|}{ Kedalaman Tanah 0-15 cm } \\
\hline Kontrol & $10 \mathrm{YR}$ & $6 / 6$ & Kuning Kecoklatan \\
\hline TKKS & $10 \mathrm{YR}$ & $6 / 4$ & Coklat Muda Kekuningan \\
\hline LC & $10 \mathrm{YR}$ & $5 / 4$ & Coklat Kekuningan \\
\hline TKKS + LC & $10 \mathrm{YR}$ & $4 / 4$ & Coklat Tua Kekuningan \\
\hline
\end{tabular}

Dari hasil pengamatan warna tanah (Tabel 6) dapat dilihat bahwa tanah dengan aplikasi limbah PPKS yang lebih banyak memiliki kandungan bahan organik lebih tinggi sehingga dapat dikatakan lebih subur dan warna tanah lebih gelap dibandingkan dengan aplikasilimbah secara tunggal. Hal ini didukung oleh Sumarno, et al. (2009) menyatakan bahwa tanah yang diberikan bahan organik memberikan warna gelap atau kehitaman sebagai indikasi tanah subur. Njurumana, et al. (2008) menambahkan bahwa makin tinggi kandungan bahan organik, maka warna tanah akan semakin gelap. 


\section{KESIMPULAN}

Dari hasil penelitian dapat diambi lkesimpulan bahwa aplikasi campuran TKKS + LC meningkatkan kadar air tanah dan menurunkan bulk density secara nyata serta cenderung meningkatkan total ruang pori dan permeabilitas dan cenderung menurunkan particle density dibandingkan kontrol, tetapi tidak nyata bila dibandingkan aplikasi TKKS dan LC secara tunggal. Aplikasi limbah PPK C berpengaruh terhadap warna tanah din tanah berwarna hitam pada aplikasi campuran TKKS + LC (hue: 10 YR, value/chroma : 2/1), berwarna cokelat pada aplikasi TKKS (hue: 10 YR, value/chroma : 4/3), berwarna cokelat tua pada aplikasi LC (hue: $10 \mathrm{YR}$, value/chroma : 3/3) dan berwarna cokelat kekuningan pada tanpa aplikasi (hue: $10 \mathrm{YR}$, value/chroma : 5/4).

\section{DAFTAR PUSTAKA}

Arsyad, S. 2000. Pengawetan Tanah dan Air. Departemen Ilmu - ilmu Tanah. Fakultas Pertanian. IPB. Bogor.

Darnoko, D., Poeloengan, Z. dan Anas, I. 1993. Pembuatan Pupuk Organik dari Tandan Kosong Kelapa Sawit. Buletin PPKS.

Dinas Perkebunan dan Pertanian Provinsi Riau. 2015. Data Statistik Perkebunan. Provinsi Riau. Pekanbaru.

Hardjowigeno, S. 2003. Ilmu Tanah. Akademik Pressindo. Jakarta.

Ichriani, G.I., T.A Atikah, S. Zubaidah dan R. Fatmawati. 2012. Kompos Tandan Kosong Kelapa Sawit untuk Perbaikan Daya Simpan Air Tanah Kapasitas Lapangan. Journal Agroscientiae, volume 9 (3).

Irvan. 2010. Pengaruh Aplikasi Pupuk Hayati Mikoriza-tricoderma sp. dan Pengurangan Dosis Pupuk N, P, K terhadap Beberapa Sifat Fisik Tanah pada Tanaman Jahe Di tanah Ultisol Banyumas. Skripsi Fakultas Pertanian. Universitas Jenderal Soedirman. Purwokerto (tidak dipublikasikan).

Islami, T dan Utomo, W.H. 1995. Hubungan Tanah, Air dan Tanaman. IKIP Semarang Press. Semarang.

Kartasapoetra. 2005. Teknologi Konservasi Tanah dan Air. Rineka Cipta. Jakarta
Ketaren, E.F. 2010. Evaluasi Sifat Fisik, pH, dan C-organik Tanah Akibat Aplikasi Limbah Cair Pabrik Kelapa Sawit di PT. Smart Padang Halaban Kabupaten Labuhan Batu Utara. Skripsi Fakultas Pertanian Universitas Sumatera Utara, Medan. (Tidak dipublikasikan).

Lumbanraja, P. 2012. Pengaruh Pemberian Pupuk Kandang Sapi dan Jenis Mulsa terhadap Kapasitas Pegang Air Tanah dan Pertumbuhan Tanaman Kedelai (Glycine max L) Var. Willis pada tanah Ultisol Simalingkar. Jurnal Ilmiah Pendidikan Tinggi (JURIDIKTI), volume 5 (2).

Mariana, H. 2006. Pengaruh Kompos Ampas Tapioca dan Pemberian Air terhadap Ketersediaan Air dan Pertumbuhan Tanaman Sawi (Brassica juncea L.) pada Entisol Wajak, Malang. Skripsi Jurusan Tanah Fakultas Pertanian Universitas Sriwijaya. (Tidak dipublikasikan).

Mauli, R.L. 2008. Kajian Sifat Fisika dan Kimia Tanah Akibat Sistem Rotasi Penggunaan Lahan Tembakau Deli. Universitas Sumatera Utara. Medan.

Muyassir, Sufardi dan I. Saputra. 2012. Perubahan Sifat Fisika Inceptisol Akibat Perbedaan Jenis dan Dosis Pupuk Organik. Jurnal Lentera, volume 12 (1).

Njurumana, G. N. D., Hidayatullah, M., Butarbutar, T. 2008. Kondisi Tanah Pada Sistem Kaliwu dan Mawar di Timor dan Sumba. Balai Penelitian Kehutanan Kupang. Kupang.

Sarief, S. 1989. Fisika-Kimia Tanah Pertanian. Pustaka Buana. Bandung.

Soil Survey Staff. 1990. Kunci Taksonomi Tanah, Edisi Kedua. Pusat Penelitian Tanah dan Agroklimat, Balai Penelitian dan Pengembangan Pertanian. Bogor.

Stevenson, F. J. 1997. Humus Chemistry. Genesis Composition Reaction. John Wiley and Son. New York.

Subagyo, H., Suharta dan A.B. Siswanto. 2000. Tanah-Tanah Pertanian di Indonesia. Pusat Penelitian Tanah dan Agroklimat. Badan Penelitian dan Pengembangan Pertanian. Bogor.

Sumarno., Unang, G., Pasaribu, D. 2009. Pengayaan Kandungan Bahan Organik Tanah Mendukung Keberlanjutan 
Sifat Fisika Tanah Perkebunan Kelapa Sawit (Elaeis guineensis Jacq.) Setelah Diaplikasi Tandan Kosong Kelapa Sawit dan Limbah Cair Pabrik Kelapa Sawit

Sistem Produksi Padi Sawah. Iptek

Tanaman Pangan. Bogor.

Yulnafatmawita, Adrinal, dan Daulay, A.F.

2008. Pengaruh Pemberian Beberapa

Jenis Bahan Organik Terhadap Stabilitas

Aggregat Tanah Ultisol Limau Manis.

Jurnal Solum, volume 5 (1). 